\title{
Age and growth of European barbel Barbus barbus (Cyprinidae) in the small, mesotrophic River Lee and relative to other populations in England
}

\author{
L. Vilizzi ${ }^{(1) \star}$, G.H. Copp ${ }^{(2),(3)}$, J.R. Britton ${ }^{(3)}$ \\ Received November 15, 2012 \\ Revised March 18, 2013 \\ Accepted May 16, 2013
}

Key-words: habitat, conservation, scale ageing, recruitment

\section{ABSTRACT}

Suspected of being in decline, the European barbel Barbus barbus population of the River Lee, a heavily-modified river in South East England, has been the subject of investigations to identify factors associated with perceived population decreases. Population surveys between 1995 and 1999 captured a total of 912 individuals, and standard length (SL) frequency analyses between years suggested that the population decline was not related to juvenile recruitment but rather to a recruitment bottleneck in fish 300-340 mm SL. This bottleneck probably results from insufficient available habitat suitable to this size class. Of the sampled fish, scales were removed from 764 and were used in a scale ageing exercise among three researchers. Analyses of their independent age estimates revealed variable interpretations, which arose from uncertainties relating to the difficulty of analysing scale patterns from relatively large, slow-growing fish. Nevertheless, error was within published acceptable margins, and age estimates revealed $B$. barbus in the river to age 10 years, lower than in many UK rivers. The SL-at-age growth curve was characterised by very fast growth in the initial years of life. Thus, the causal factors in the decline of this $B$. barbus population appear to have been in the adult life-stage habitat and were likely related to the loss of longitudinal connectivity, mainly due to the presence of water retention structures. River and aquatic ecosystem remediation strategies should therefore focus on enhancing longitudinal connectivity in conjunction with the ongoing improvement of water quality and ecosystem integrity.

\section{RÉSUMÉ}

L'âge et la croissance du barbeau européen Barbus barbus (Cyprinidés) dans la petite mésotrophique rivière Lee et comparaison à d'autres populations en Angleterre

\begin{abstract}
Mots-clés :
Soupçonnée d'être en déclin, la population de barbeau européen Barbus barbus habitat, conservation, scalimétrie, recrutement de la rivière Lee, une rivière fortement modifiée dans le Sud Est de l'Angleterre, a fait l'objet d'investigations pour identifier les facteurs associés à la diminution ressentie de la population. Le suivi de population entre 1995 et 1999 a permis la capture de 912 poissons, et l'analyse des fréquences de longueur standard (SL) entre années suggère que le déclin de la population n'était pas lié au recrutement des juvéniles, mais plutôt à un goulot d'étranglement du recrutement chez les poissons de 300-340 mm SL. Ce goulot d'étranglement résulte probablement d'une insuffisance de l'habitat disponible approprié pour cette classe de taille.
\end{abstract}

(1) Murray-Darling Freshwater Research Centre, PO Box 991, Wodonga Vic 3689, Australia

(2) Salmon \& Freshwater Team, Cefas, Pakefield Road, Lowestoft, Suffolk, NR33 OHT, UK, and Environmental and Life Sciences Graduate Program, Trent University, Peterborough, Canada

(3) Centre for Conservation Ecology and Environmental Change, School of Applied Sciences, Bournemouth University, Fern Barrow, Poole, Dorset UK

^ Corresponding author: Iorenzo.vilizzi@tin.it 
Des poissons échantillonnés, les écailles ont été prélevées sur 764 individus et utilisées pour un exercice de détermination de l'âge par trois chercheurs. Les analyses de leurs estimations de l'âge ont révélé des interprétations variables, provenant des incertitudes liées à la difficulté d'analyser les écailles de relativement gros poissons à croissance lente. Néanmoins, l'erreur était à l'intérieur des marges acceptables publiées, et les estimations d'âge ont révélé des $B$. barbus dans la rivière jusqu'à 10 ans d'âge, inférieur à celui observé dans de nombreux cours d'eau du Royaume-Uni. La courbe de croissance SL selon l'âge a été caractérisée par une croissance très rapide au cours des premières années de la vie. Ainsi, les facteurs de causalité dans le déclin de cette population de $B$. barbus paraissent avoir été liés à l'habitat des stades adultes et sont probablement liés à la perte de connectivité longitudinale, principalement en raison de la présence de structures de rétention d'eau. Les stratégies de restauration des rivières et des écosystèmes aquatiques devraient donc se concentrer sur l'amélioration de la connectivité longitudinale en collaboration avec l'amélioration permanente de la qualité de l'eau et de l'intégrité de l'écosystème.

\section{INTRODUCTION}

The European barbel Barbus barbus (L.) has considerable socio-economic importance as a sport fish (Britton and Pegg, 2011) and although is classed on the IUCN Red List as being of 'Least Concern', it is increasingly seen as 'flag' species for river conservation. Increasingly threatened within its native range (Peňáz et al., 2003), the IUCN status of $B$. barbus therefore carries the caveat of being "locally threatened by water pollution and river regulation". In the UK, where B. barbus is native to eastern rivers between Yorkshire and the Thames (Wheeler and Jordan, 1990), declining population densities have been reported for some of the more urbanised rivers, including the River Lee, Hertfordshire (Pilcher and Copp, 1997; Watkins et al., 1997). River regulation has been identified as a major threat to barbel populations (Pilcher et al., 2004), with compounding adverse effects of elevated nutrient levels on the species' morphology (Tyler and Everett, 1993), physiology (Peňáz et al., 2005) and migratory behaviour (Lucas and Frear, 1997; Vilizzi et al., 2006). This contrasts with earlier, more optimistic assessments that suggested that $B$. barbus numbers were on the increase (Wheeler and Jordan, 1990). Thus, information on population size structure and growth is needed for rivers where $B$. barbus stocks are thought to be in decline so as to inform environmental managers in the formulation of habitat enhancement/rehabilitation and re-stocking strategies that aim to conserve the populations and increase the related angling amenity (Britton and Pegg, 2011; Pegg and Britton, 2011).

To investigate a perceived decline in the $B$. barbus population of the River Lee, a small mesotrophic water course in South East England, collaborative research focused on the possible casual factors (Copp and Bennetts, 1996; Pilcher and Copp, 1997) through studies of the species' environmental biology (e.g. Watkins et al., 1997; Vilizzi and Copp, 2001, 2013a,b; Copp et al., 2002, 2005; Vilizzi et al., 2006). As a component part of this research programme, the aim of the present study was to assess the age and growth rates of River Lee $B$. barbus. Specific objectives were to: 1 ) determine inter-annual variation in population size structure; 2 ) assess seasonal and inter-annual variation in growth; and 3) compare the growth of $B$. barbus in the River Lee with other stocks throughout England.

\section{MATERIAL AND METHODS}

\section{> STUDY AREA}

The River Lee (catchment area $=1420 \mathrm{~km}^{2}$; human population $\approx 2$ million) is one of the most heavily human-impacted river systems in the UK, with treated sewage effluent $\left(11000 \mathrm{~m}^{3} \cdot \mathrm{d}^{-1}\right)$ representing up to $80 \%$ of the river's discharge during periods of low flow (NRA 1994a; Faulkner and Copp, 2001), which has consequences for the character of the river substratum (clogging with silt and biofilms, resulting in reduced sediment mobility; Vilizzi et al., 2006). 
A major left-bank tributary of the River Thames, the R. Lee is of chalk stream origin, with a mean annual discharge of $1.09 \mathrm{~m}^{3} \cdot \mathrm{s}^{-1}$ (Faulkner and Copp, 2001). The study stretch comprised three reaches in the upper course of the river, where the river bed slope is $\approx 2.93 \mathrm{~m} \cdot \mathrm{km}^{-1}: 1$ ) from Lemsford Reserve $(51.793946 \mathrm{~N}, 0.22895873 \mathrm{~W})$ to Stanborough Park (51.787283N; 0.22236586W); 2) from Holwell Bridge (51.772461N; $0.15165210 \mathrm{~W})$ to Letty Green Bridge (51.773503N; 0.14358401W); and 3) from Letty Green Bridge to the eastern extent of Woolmers Park (51.771418N; 0.12814522W) (Figure 1).

Reach 1 (Lemsford-Stanborough) was about $1800 \mathrm{~m}$ in length and was characterised by a substratum of mainly sand and gravel, with occasional silt and large rocks. From upstream to downstream, riparian vegetation went from thick and abundant (in the nature reserve) to patchy and relatively thin as the river flows through the park. Channel width varied 6-10 $\mathrm{m}$, with water depths mostly $<0.5 \mathrm{~m}$ except in one occasional pool (maximum depth $=2 \mathrm{~m}$ ). Management of the stream course was virtually nil upstream, but manicured downstream in the park.

Reach 2 (Holwell-Letty Green) had a length of $\approx 1000 \mathrm{~m}$ and is situated $\approx 9$ river km downstream of Reach 1, flows through unfenced, private (sheep) pasture land, where the river substratum varied considerably (i.e. silt and fine sand in back-eddy areas adjacent to pool, with gravel and cobbles in the riffle sections). From upstream to downstream, riparian vegetation went from a thin strip of trees and bushes to open field with only a few overhanging trees and occasional reed beds. Water depth varied from shallows of $<20 \mathrm{~cm}$ to deep $(>1.5 \mathrm{~m})$ bends. Management of the stream edges was not apparent, with sheep trampling of the shallower stream banks.

Reach 3 (Letty Green-Woolmers) was about $700 \mathrm{~m}$ long and flows through a private estate, beginning upstream with a sinuous section that passes through a small, thick wood, leading into a more open section bordered by a few trees, passing under a driveway bridge, which has a deep ( $>2 \mathrm{~m}$ ) downstream of it. The river then passes into a sequence of runs, pools and riffles that begins within a fenced pasture area (cows) followed by thick woodland in which the river is joined by a small, short stream. The riparian border varied from virtually nothing (mostly fencing and tall wild grasses) to $>40 \mathrm{~m}$ width. Stream width was 3-12 $\mathrm{m}$, with depths up to $2 \mathrm{~m}$ or $3 \mathrm{~m}$. In-stream management had been limited to the removal of fallen trees and bushes (see Copp and Bennetts, 1996).

None of the reaches is open to angling activity except at the extreme downstream end of Reach 2. River discharge varied between 0.5 and $5.0 \mathrm{~m}^{3} \cdot \mathrm{s}^{-1}$; discharge peaks usually occurred in winter and daily flow patterns were strongly influenced by discharges of treated domestic effluent (Faulkner and Copp, 2001). However, only the Lemsford Reserve stretch (the closest to the upstream treatment plant) has occasionally been found to fail non-statutory river quality objectives (NRA, 1994b; Copp et al., 2007). Combined with surface run-off from agricultural land, the water quality of the river is typically mesotrophic. Generally consistent with the barbel zone (Huet, 1949), other fish species present (in relatively high abundance) were chub Leuciscus cephalus, European minnow Phoxinus phoxinus, gudgeon Gobio gobio, stone loach Barbatula barbatula, European bullhead Cottus gobio and dace Leuciscus leuciscus, with occasional occurrences of roach Rutilus rutilus, perch Perca fluviatilis, threespine stickleback Gasterosteus aculeatus and (stocked) brown trout Salmo trutta (Copp and Bennetts, 1996; Pilcher and Copp, 1997; Copp et al., 2005). In this part of the river, benthic invertebrates have been found to be dominated by Baetis rhodani, Ephemerella ignita and Chironomidae larvae (Copp et al., 2005), and drifting invertebrates by Caenis robusta, $B$. rhodani, E. ignita, Asellus aquaticus and Chironomidae (Edmonds-Brown et al., 2004).

\section{> FISH COLLECTION AND MEASUREMENT}

Barbus barbus were collected during 58 scheduled and incidental sampling excursions (Vilizzi et al., 2006) between August 1995 and April 1999. Fish were captured using a back-pack electrofishing unit (Deka 3000: Deka-Geratebau, Rudolf Muhlenbein, VincentiusstraBe 13, 3538 Marsberg, Germany) whilst fishing in an upstream direction. Previous depletion sampling 
revealed the maximum standard length (SL) size of $B$. barbus in Reach 3 to be of $450 \mathrm{~mm}$ (Copp and Bennetts, 1996), and more widely in the River Lee rarely exceed $500 \mathrm{~mm}$ (G.H. Copp, unpublished data). Upon capture, fish were measured (nearest $\mathrm{mm}$ ) for SL, fork (FL) and total length (TL), weighed (nearest g) and examined for sex (using external features and running sexual products during the reproductive season only, typically May to July). Up to five un-regenerated scales were removed from the antero-medial region of the body immediately below the lateral line (Peňáz and Štouračová, 1991), cleaned of mucus and stored in paper envelopes for subsequent examination. In the laboratory, scales were mounted between glass slides after soaking briefly in $20 \%$ sodium hypochlorite and rinsing in distilled water. The criteria of Chugunova (1963) were followed for annulus identification, with the scales inspected with a dissecting microscope (10-20x) under transmitted light. An annulus was taken as a transition between two uninterrupted zones of closely- and widely-spaced circuli, with anastomosis as an essential criterion for identification. To ensure the consistency of age interpretation, three interpreters (A, B and C) counted annuli on the scales under study. Whenever the pattern of closely- and widely-spaced circuli could not be consistently identified the preparation was scored as 'uninterpretable'. The interpreters were given no indication of the date of capture, length or weight of the fish.

\section{> DATA ANALYSIS}

Inter-annual variation in size structure was examined by plotting of length-frequency distributions from 1995 to 1998, with each year taken to represent the 'growth season' of the three 'biological seasons' (i.e. reproduction, growth, over-winter) as described by Cattanéo (2005). For $B$. barbus, the growth season (i.e. when fish are feeding actively) was nominally taken as starting on June 1. Annual size structures were summarised using proportional stock density (PSD), which was calculated as the ratio of quality-sized fish to stock-sized fish (cumulative sums) multiplied by 100 . The following size classes (TL) were defined (Abernethy, 2006): (i) "Zero" fish $(<280 \mathrm{~mm})$ have little recreational value being smaller than stock size, but ecologically represent an indicator of successful recruitment (i.e. young-of-year and immatures, noting that male barbel generally mature at a smaller size than females); (ii) 'Stock' fish (280$410 \mathrm{~mm}$ ) have a minimum size of 20-26\% of the world-record length; (iii) 'Quality' fish (410$530 \mathrm{~mm}$ ) fall into the $36-41 \%$ range and are generally of appeal to anglers; (iv) 'Preferred' (530-660 mm; 45-55\%) are of even higher appeal; (v) 'Memorable' (660-840 mm; 59-64\%) is the size most anglers remember catching; and (vi) 'Trophy' (>840 mm; 74-80\%) is a size considered worthy of acknowledgement. Notably, the percentage ranges for each size class correspond to appropriately defined portions of the Weithman's sigmoid curve (Gabelhouse, 1984). For each year of sampling, $P S D$ was computed in the $R$ language and software environment v2.14.2 (R Development Core Team, 2010) using libraries FSA and NCStats (Ogle, 2011a). Given the similarity in maximum reported size for $B$. barbus and common carp Cyprinus carpio carpio (www.fishbase.org), the size classes for the latter species as provided in Ogle (2011a) were extrapolated to $B$. barbus.

Bias and precision of annulus counts were analysed by statistical and graphical methods for each pair of replicate counts from the three interpreters. Accordingly, an age bias plot (Campana et al., 1995) was generated and a test of symmetry (Hoenig et al., 1995) computed from the corresponding age-agreement table. In this table, the main diagonal represents the frequency of fish for which the same estimated age is obtained by any combination of two interpreters, whereas each cell off the main diagonal represents a difference in estimated age between the interpreters. If there are no systematic differences between interpreters, then it is expected that the disagreements in estimated age would fall randomly on either side of the diagonal, producing an approximately symmetric age-agreement table. Precision, defined as the reproducibility of estimated ages between interpreters (Campana, 2001), was computed as percentage agreement, average percent error (APE), and by the coefficient of variation (CV). All computations were in R using libraries FSA and NCStats and following guidelines in Ogle (2011b). 
Growth of $B$. barbus in the River Lee was described in terms of weight-SL (WL), SL-at-age (LAA), and weight-at-age (WAA) relationships both for the entire stock and for males and females separately. For computation of LAA and WAA relationships, the mean estimated age from the three interpreters was adjusted by taking June 1 as the nominal hatching date of each annual cohort in the sampled stock, with the final estimated age of each fish expressed as a decimal:

$$
\text { age (as integer) + (days from June } 1 \text { to date of capture) / 365.25. }
$$

Fitting of WL relationships and of the von Bertalanffy growth model (VBGM) to LAA and WAA data was in R using libraries FSA, NCStats and nlstools and following guidelines in Ogle $(2011 \mathrm{c}, \mathrm{d})$. For the VBGM, which has been found to provide unrealistic estimates of ultimate size (Živkov et al., 1999; Copp et al., 2004), both the Beverton-Holt and Gallucci-Quinn parameterisations were used, the former providing estimates of $S L_{\text {inf }}$ (or $W_{\text {inf }}$ ), $k$ and $t_{0}$ for comparisons with other studies and the latter facilitating between-sex comparisons by means of parameter $\omega=\mathrm{FL}_{\text {inf }} \cdot k$ (or $W_{\text {inf }} \cdot k$ ), which has been shown to capture the essential features of growth and to facilitate growth-rate comparisons (Charnov, 2010). For WAA growth computations, the Beverton-Holt adaptation of the VBGM was used (Ricker, 1975), but with the slope parameter fixed at $b=3$ due to computational constraints. Following Ogle (2011d), between-sex growth comparisons were by hierarchical fitting of eight VBGMs in total under both parameterisations as follows: (i) a general model with separate parameter estimates for individuals of each sex; (ii) three models with one parameter in common between sexes; (iii) three models with two parameters in common between sexes; and (iv) one common model with the same parameter estimates for both sexes (also to account for uncertainty in sexing some individuals). After fitting of the individual models, the Akaike (AIC) and Bayesian Information Criterion (BIC) were computed to select the best-fitting model, with preference given to $\mathrm{BIC}$ in case of disparity of outcomes for reasons of model parsimony (Burnham and Anderson, 2003). Notably, SL was used as the reference measure for length in all growth models. This was to facilitate comparisons with other $B$. barbus stocks (see below) and because SL (or, equivalently, FL) measurements are not affected by possible damages or erosion of the lobes of the caudal fin.

Mean LAA values (combined sexes) for $B$. barbus stocks from rivers throughout England were collated from literature as well as unpublished data, with FL converted into SL whenever applicable (conversion factor as per www.fishbase.org). Both the VBGM and a log-log quadratic model (LLQM) were fitted to the LAA data for each stock (cf. Vilizzi and Walker, 1999; Britton et al., 2012). Fitting of the VBGM was in FiSAT II v1.2.2 (www.fao.org) using a maximum $\mathrm{SL}$ value of $1000 \mathrm{~mm}$ (maximum reported length for $B$. barbus; anonymous reviewer, pers. comm.) and with a starting $t_{0}$ value ranging from -2 to 2 (or fixed at 0 in case of lack of fit). Whenever the VBGM could not be fitted because of less than seven LAA values in a stock, or due to linear (i.e. non-asymptotic) growth, the stock was excluded from analysis. Also, for consistency with the other stocks the VMGM was re-fitted to the River Lee $B$. barbus stock of the present study based on the mean LAA values. Fitting of the LLQM was in S-Plus 6 Professional for Windows ${ }^{\circledR}$. The resulting VBGM and LLQM parameters for the different $B$. barbus stocks were then subjected separately to principal component analysis (PCA) following normalisation (PRIMER v6: Clarke and Gorley, 2006). Finally, for the VBGM the growth parameters $\varphi^{\prime}$ and $\omega$ were also computed for each stock (Živkov et al., 1999; Charnov, 2010), and an overall VBGM curve was fitted to the LAA data from all available $B$. barbus stocks from England (i.e. including those for which a VBGM and/or a LLQM could not be fitted because of the above constraints) using the same fitting procedures as above for the R. Lee population.

\section{RESULTS}

In total, 912 B. barbus were captured between 1995 and 1998, of which 148 from Reach 1, 396 from Reach 2, and 368 from Reach 3. The largest size achieved was $500 \mathrm{~mm} \mathrm{SL}$, the largest weight $2000 \mathrm{~g}$, and the oldest estimated age 10 years (sex unknown). 


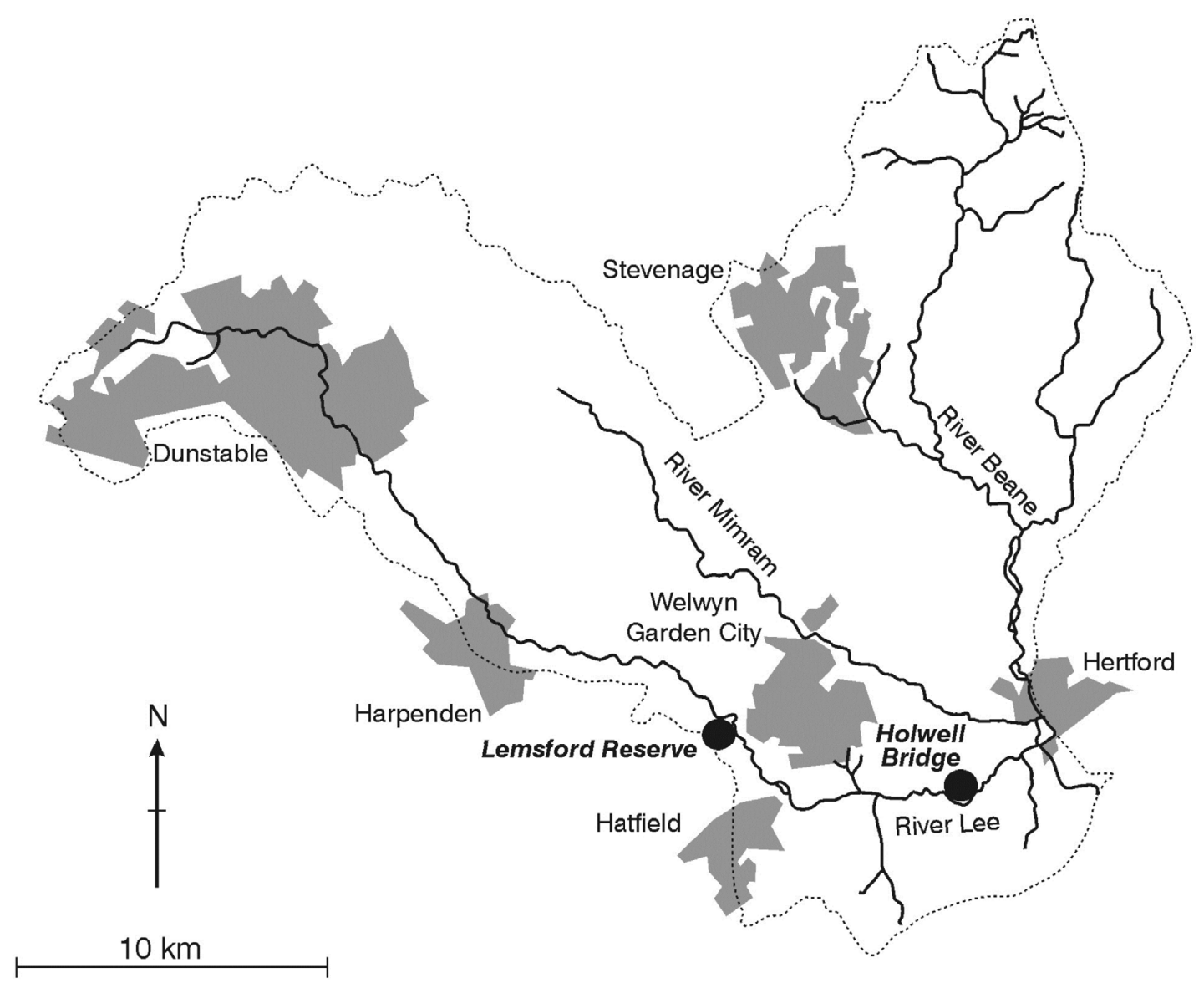

\section{Figure 1}

The three study reaches on the River Lee (Hertfordshire, England): Reach 1, extending downstream from Lemsford Reserve to Stanborough Park; Reach 2, extending from Holwell Bridge to Letty Green Bridge; and Reach 3, extending from Letty Green Bridge to the eastern extent of Woolmers Park.

\section{Table I}

Inter-annual variation in size structure (total number and relative percentage of fish) and proportional stock density (PSD, with 95\% confidence intervals) of European barbel Barbus barbus in the River Lee. $Z$ = Zero; $S$ = Stock; $Q=$ Quality; $P=$ Preferred; $M=$ Memorable; $T=$ Trophy (see text for definition of size classes). See also Figure 2.

\begin{tabular}{|c|c|c|c|c|c|c|c|c|}
\hline \multirow[b]{2}{*}{ Year } & \multirow[b]{2}{*}{$n$} & \multicolumn{6}{|c|}{ Size class } & \multirow[b]{2}{*}{ PSD } \\
\hline & & $z$ & $S$ & Q & $P$ & $M$ & $\mathrm{~T}$ & \\
\hline 1995 & 196 & $76(39)$ & $35(18)$ & $81(41)$ & $4(2)$ & $0(0)$ & $0(0)$ & $71(62-78)$ \\
\hline 1996 & 70 & 46 (64) & $6(8)$ & $18(25)$ & $2(3)$ & $0(0)$ & $0(0)$ & 75 (55-88) \\
\hline 1997 & 321 & 107 (33) & 79 (24) & $135(41)$ & $8(2)$ & $0(0)$ & $0(0)$ & 63 (56-69) \\
\hline 1998 & 304 & $110(36)$ & $66(21)$ & $128(41)$ & $5(2)$ & $0(0)$ & $0(0)$ & 66 (59-72) \\
\hline
\end{tabular}

Length-frequency distributions for the four years of study were distinctively bimodal due to a predominance of fish in the smaller (Zero) and larger (Quality) size classes and a gap in the middle-sized (Stock) class (Figure 2). This pattern was reflected by the relative proportion of size classes in the R. Lee population (Table I), with Quality fish being more abundant and present in identical proportions in all years except 1996, when Zero fish were predominant. Preferred fish always represented a minor proportion of the catch, and neither Memorable nor Trophy fish were ever caught. Finally, PSD was similar in 1995 and 1996, and slightly higher in those years relative to 1997 and 1998 (Table I). 


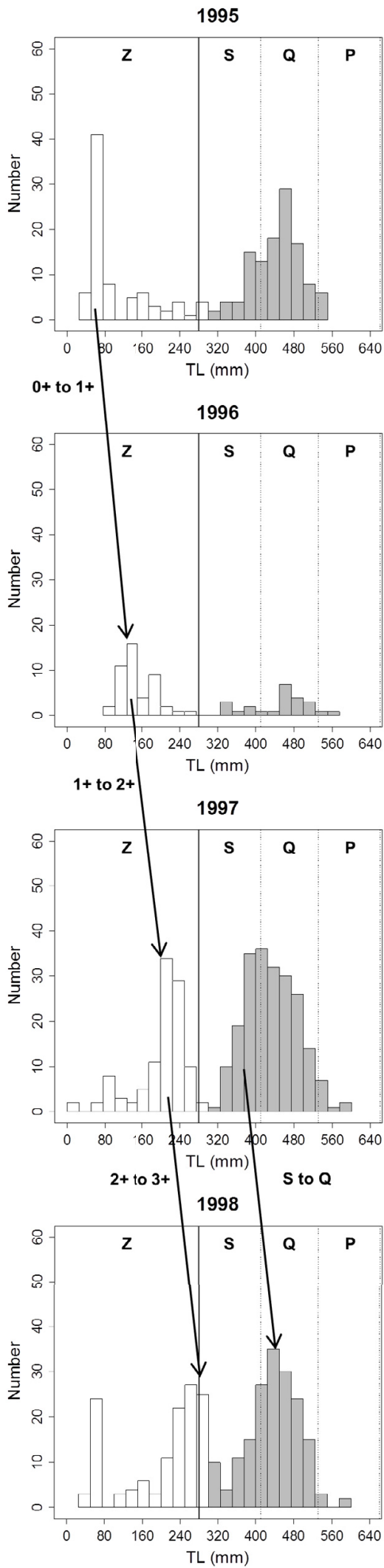

Figure 2

Size structure of $B$. barbus in the River Lee over four years of study with indication of size classes and their annual progression (0+, 1+, 2+, 3+ = age classes). $Z=$ Zero; $S=$ Stock; $Q=$ Quality; $P=$ Preferred. See also Table I. 


\section{Table II}

Bias (test of symmetry) and precision of age estimates for B. barbus in the River Lee based on scale annulus counts from three interpreters. $A P E=$ Average Percentage Error; $C V=$ Coefficient of Variation. Significant $P$ values in bold $(\alpha=0.05)$. See also Figure 3 .

\begin{tabular}{lcccccccc}
\hline & & \multicolumn{3}{c}{ Bias } & & \multicolumn{3}{c}{ Precision } \\
\cline { 3 - 5 } \cline { 7 - 9 } Interpreters & $n$ & $d f$ & $\chi^{2}$ & $P$ & & Agreement & APE & CV \\
\hline A vs. B & 673 & 28 & 36.87 & 0.122 & & 46.51 & 8.49 & 12.01 \\
A vs. C & 687 & 27 & 52.22 & $\mathbf{0 . 0 0 2}$ & & 44.25 & 9.11 & 12.88 \\
B vs. C & 687 & 26 & 46.05 & $\mathbf{0 . 0 0 9}$ & & 55.36 & 6.57 & 9.29 \\
\hline
\end{tabular}

In total, 764 scales were examined for annulus counts. The proportion of scales discarded as uninterpretable was $8.2 \%(n=58), 12.4 \%(n=84)$ and $10.1 \%(n=70)$ for interpreters $A$, $B$ and $C$, respectively. Pair-wise bias comparisons showed a tendency for interpreters $B$ and $C$ to over-estimate annulus counts beyond seven annuli (Figure 3 ), even though these differences were statistically significant only relative to interpreter $C$, hence not between interpreters A and B (test of symmetry: Table II). Conversely, agreement was higher between interpreters $B$ and $C$, whose corresponding APE and CV values were lower relative to interpreter A vs. B and C (Table II). For this reason, choice of assigning a mean estimated age to fish based on annulus counts from all three interpreters (rather than age estimates based on one interpreter only) was deemed appropriate.

The mean estimated value for the coefficient $b$ in the WL relationship was $<3$, and upon comparison between sexes there was no significant difference in slopes $(P>0.05)$, although the intercept for males was larger $(P<0.001)$ than for females (Table III, Figures $4 a, 4 b)$. Growth in SL for the entire stock was asymptotic and differed between males and females, with the latter attaining a larger asymptotic SL, which was reflected by a higher growth parameter $\omega$ (Table III, Figures 4c, 4d). Growth in weight for the entire stock also was asymptotic and differed between males and females, the latter attaining a higher asymptotic weight, which was faster in early years of life (as indicated by parameter $k$ ) compared to males (Table III; Figures $4 \mathrm{e}, 4 \mathrm{f})$.

For inter-population comparisons, mean LAA data were available for 25 English $B$. barbus stocks in total, with a maximum estimated age (scale annulus counts) of 15 years (Table IV). A VBGM could be fitted to 19 of the stocks under study, whereas a LLQM to 23 of them (Table V). Compared to other stocks, growth of $B$. barbus in the R. Lee was very fast in the first two years of life compared to most of the other stocks and was similar to that in the Severn (1974 and 2012) (Figure 5), even though growth parameters $\varphi^{\prime}$ and $\omega$ fell within the range of the stocks under study (Table V). The largest $S L_{\text {inf }}$ value was achieved by the Bristol Avon stock, and the largest $k$ (and $\omega$ ) by the 2012 Severn stock (Table V; Figure 5). The overall VBGM for the 25 English $B$. barbus stocks resulted in the growth parameters $\mathrm{SL}_{\text {inf }}=567.4( \pm 21.3 \mathrm{SE}), k=0.156( \pm 0.014 \mathrm{SE})$ and $t_{0}=0.518( \pm 0.140 \mathrm{SE})$ (Figure 6).

\section{DISCUSSION}

The size-class distributions of $B$. barbus in the R. Lee during the four years of study revealed a chronological progression of young fish through the Zero class in 1995 to 1997, and beginning to enter the Stock class by 1998 (Fig. 2). The Quality class of larger fish remained relatively constant, albeit with a dip in numbers overall in 1996. The apparent gap around 300-340 mm TL at the lower end of the Stock class resembles a recruitment bottleneck similar to that described for nase Chondrostoma nasus in regulated stretches of the upper River Rhône (Persat and Chessel, 1989). Similar to B. barbus, C. nasus is a large-bodied benthic species, and a gap in recruitment between smaller and larger size classes (extending over a range of $600 \mathrm{~mm}$ ) was attributed to insufficient suitable habitat in the by-passed, natural stretches of the river, where a minimum discharge regime is in place for hydroelectric production (Persat and Chessel, 1989). In the upper R. Lee, the main channel is not by-passed, 

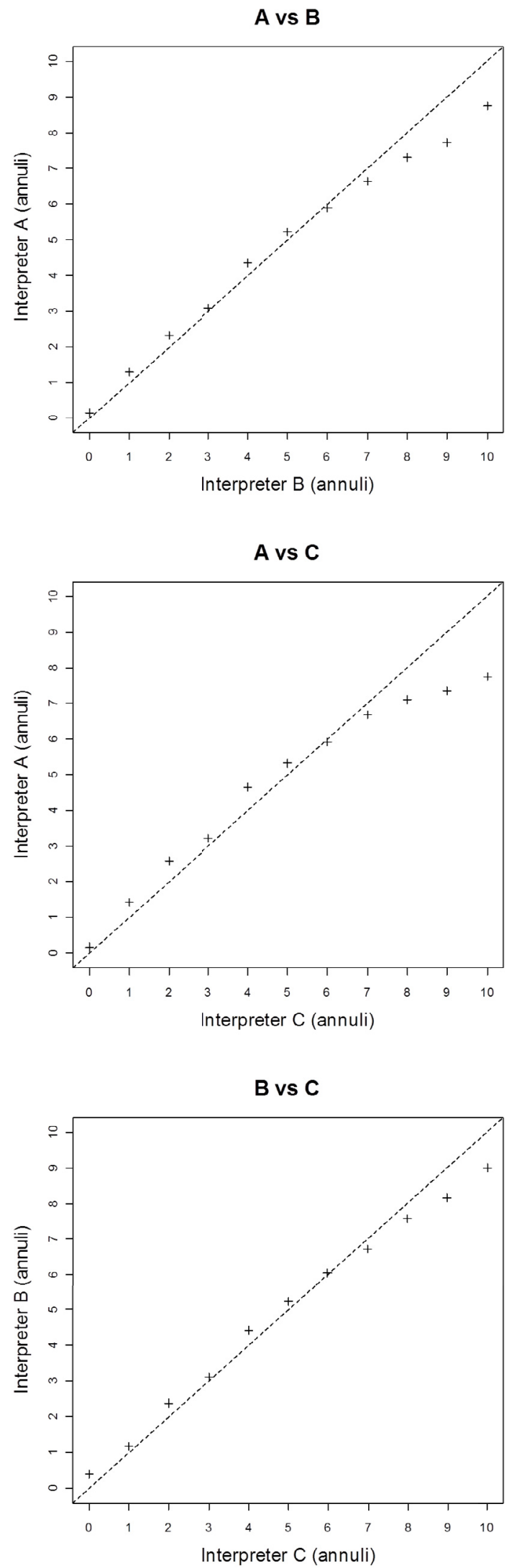

Figure 3

Age-bias plots with pair-wise comparisons of B. barbus scale annulus counts from three interpreters. See also Table II. 


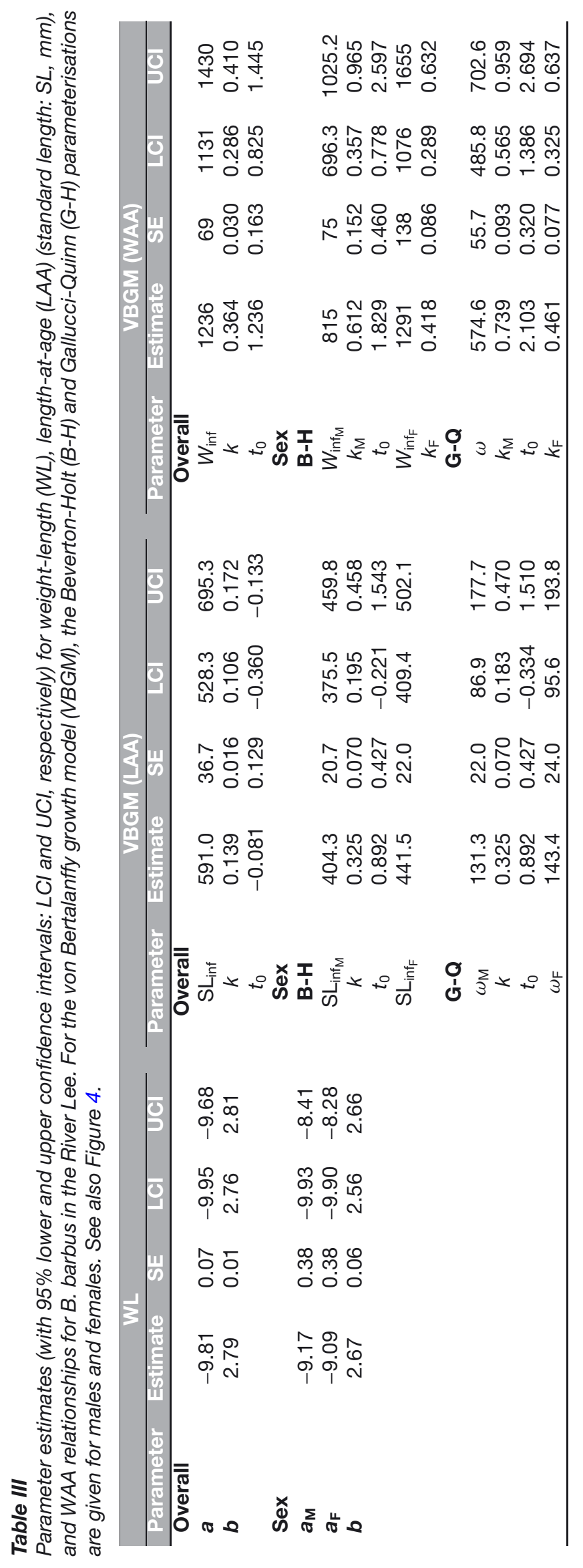



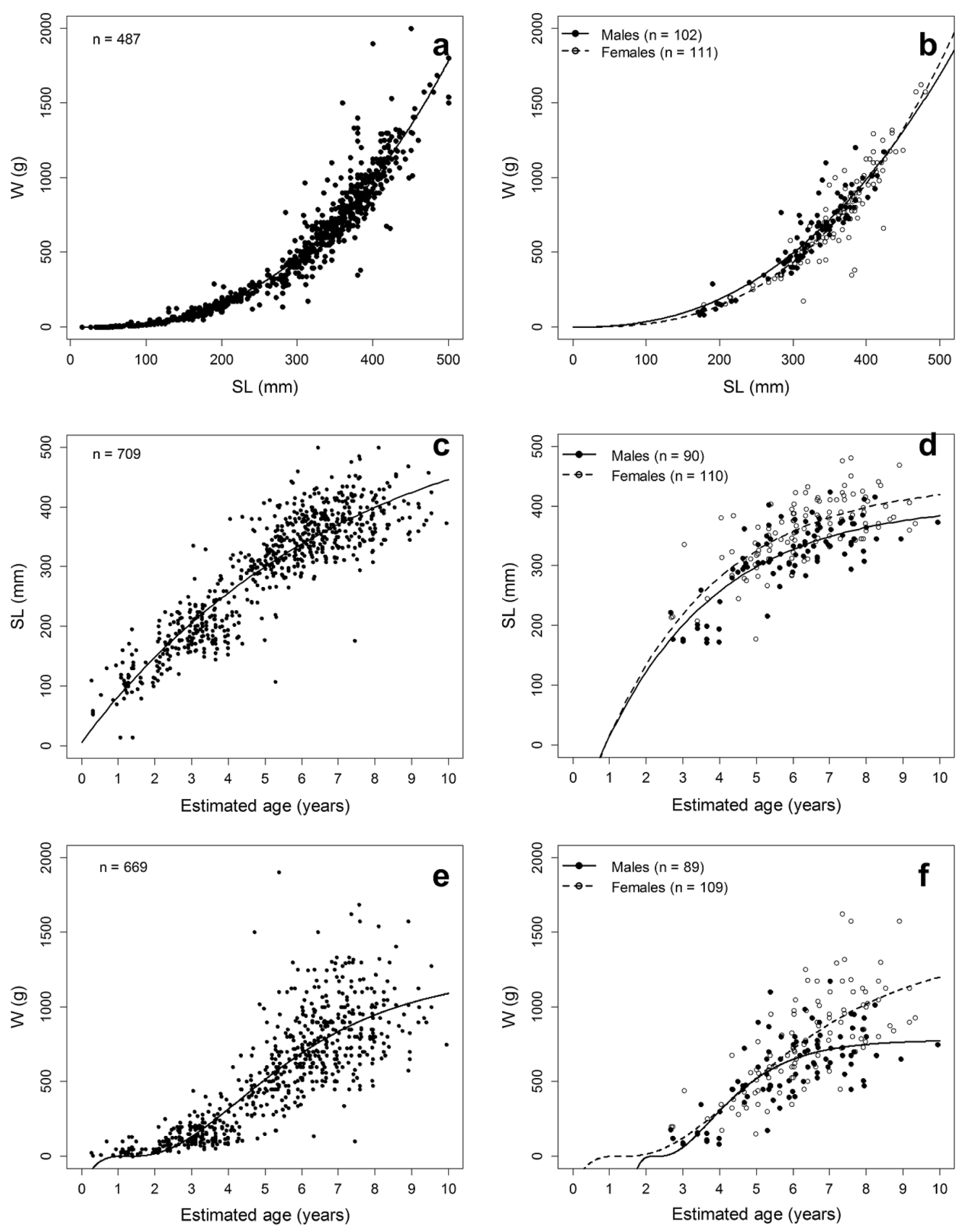

Figure 4

Growth relationships for B. barbus in the River Lee with estimated ages from scale annulus counts. (a, b) Weight-standard length relationship for the entire stock and for males and females separately; (c, d) Standard length-at-age based on the von Bertalanffy growth model (VBGM) for the entire stock and for males and females separately; (e, f) Weight-at-age based on the VBGM for the entire stock and for males and females separately. See also Table III. 
L. Vilizzi et al.: Knowl. Managt. Aquatic Ecosyst. (2013) 409, 09

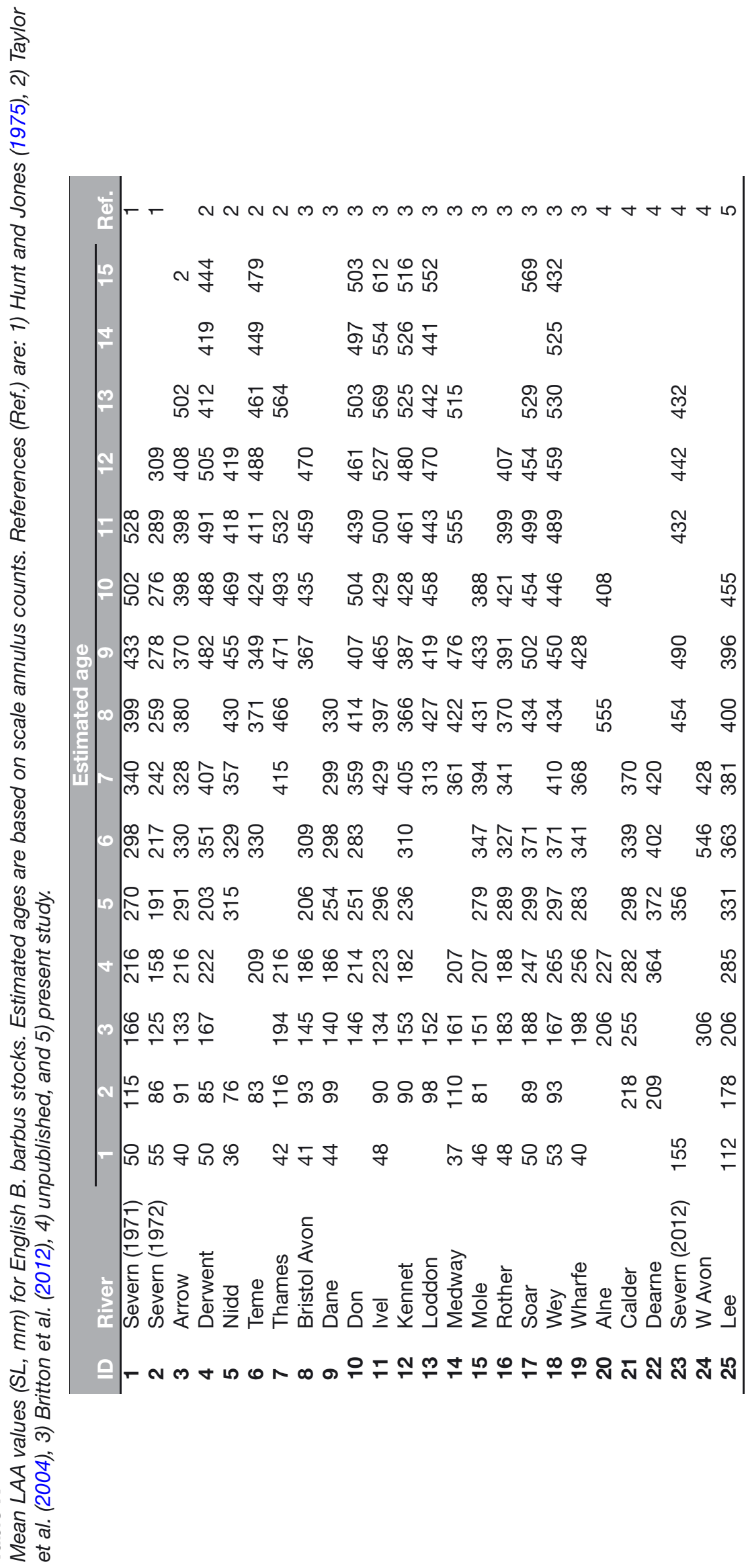




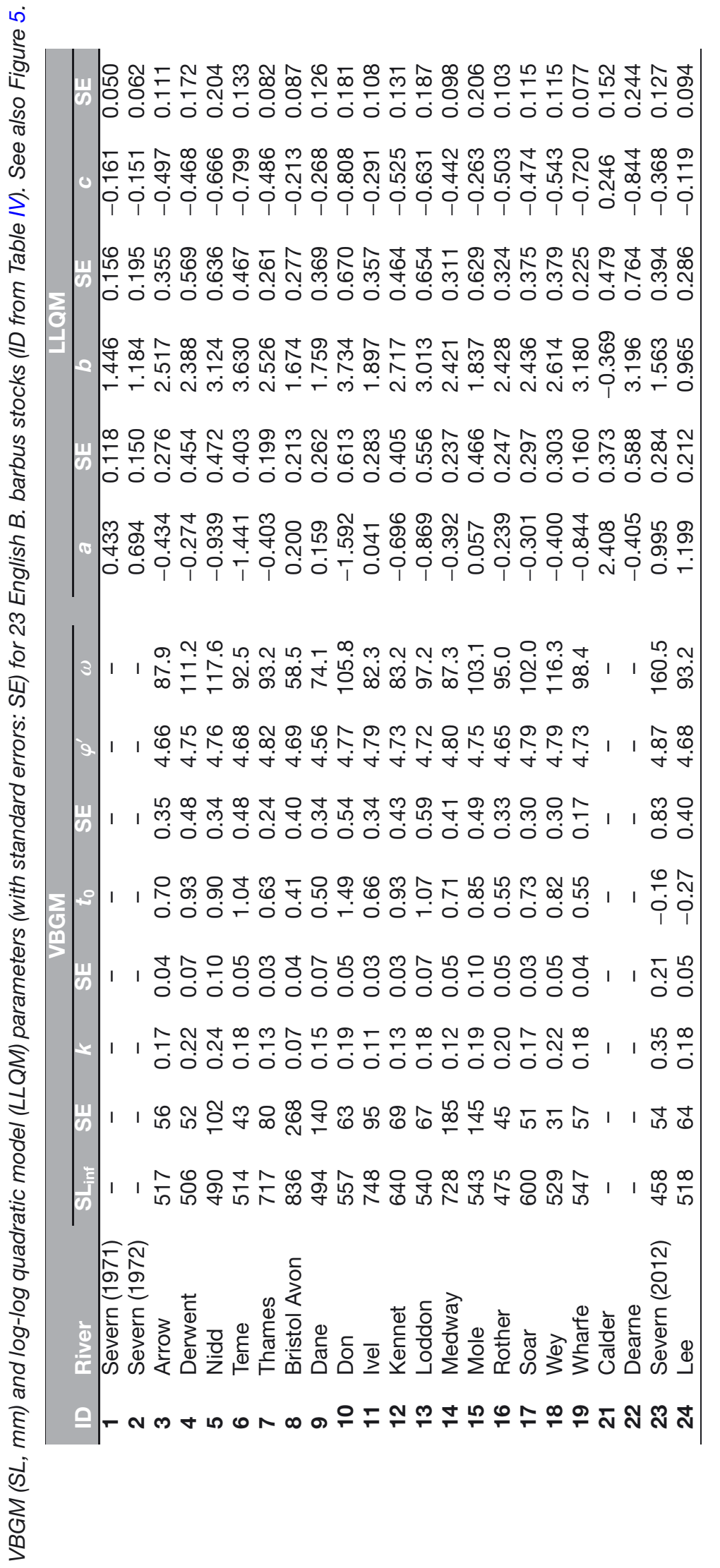



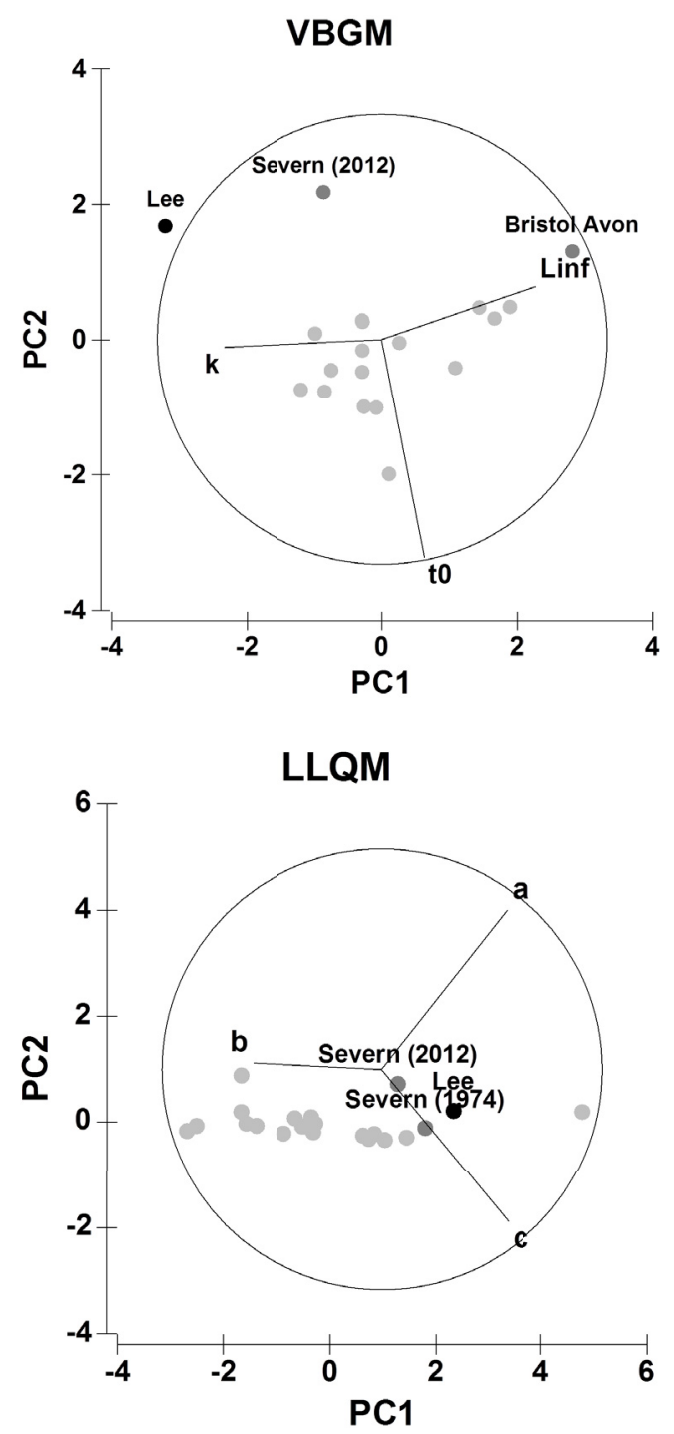

\section{Figure 5}

Principal component analysis (PCA) plot for B. barbus stocks in England based on the VBGM (top) and LLQM (bottom) parameters (cf. Table V).

but it is interrupted throughout its course by water retention structures (i.e. weirs and reservoir dams), which result in $B$. barbus movements during normal discharge conditions being restricted to the confines of consecutive weirs (Vilizzi et al., 2006). Tagged B. barbus in a concurrent study (Vilizzi et al., 2006), which encompassed Reaches 2 and 3, have been recaptured both upstream and downstream of the weirs that delimit this stretch of river; drifting $B$. barbus eggs and larvae have also been reported for this same stretch of river (Copp et al., 2002). These studies suggest that likely exceptions to confined movement include the downstream displacement of small $B$. barbus (over the water retention structures) during virtually all discharge rates, and the upstream movement by some larger $B$. barbus during extreme high discharge events (evinced by angler captures of tagged barbel; Vilizzi et al., 2006).

As such, the present study demonstrates that recruitment problems in the R. Lee may not be due to a shortage of juvenile habitat, as originally perceived (Pilcher and Copp, 1997; Watkins et al., 1997; Copp et al., 2002), but rather to some other factors that affect the intermediatesized fish, the most likely being the impediment to free movement imposed by water retention structures. Similar to C. nasus in the Upper Rhône (Persat and Chessel, 1989), the recruitment gap in $B$. barbus of the R. Lee could be due to larger fish occupying the entire 'suitable' habitat, leaving none for up-coming recruits, which are forced to move elsewhere in the system. 


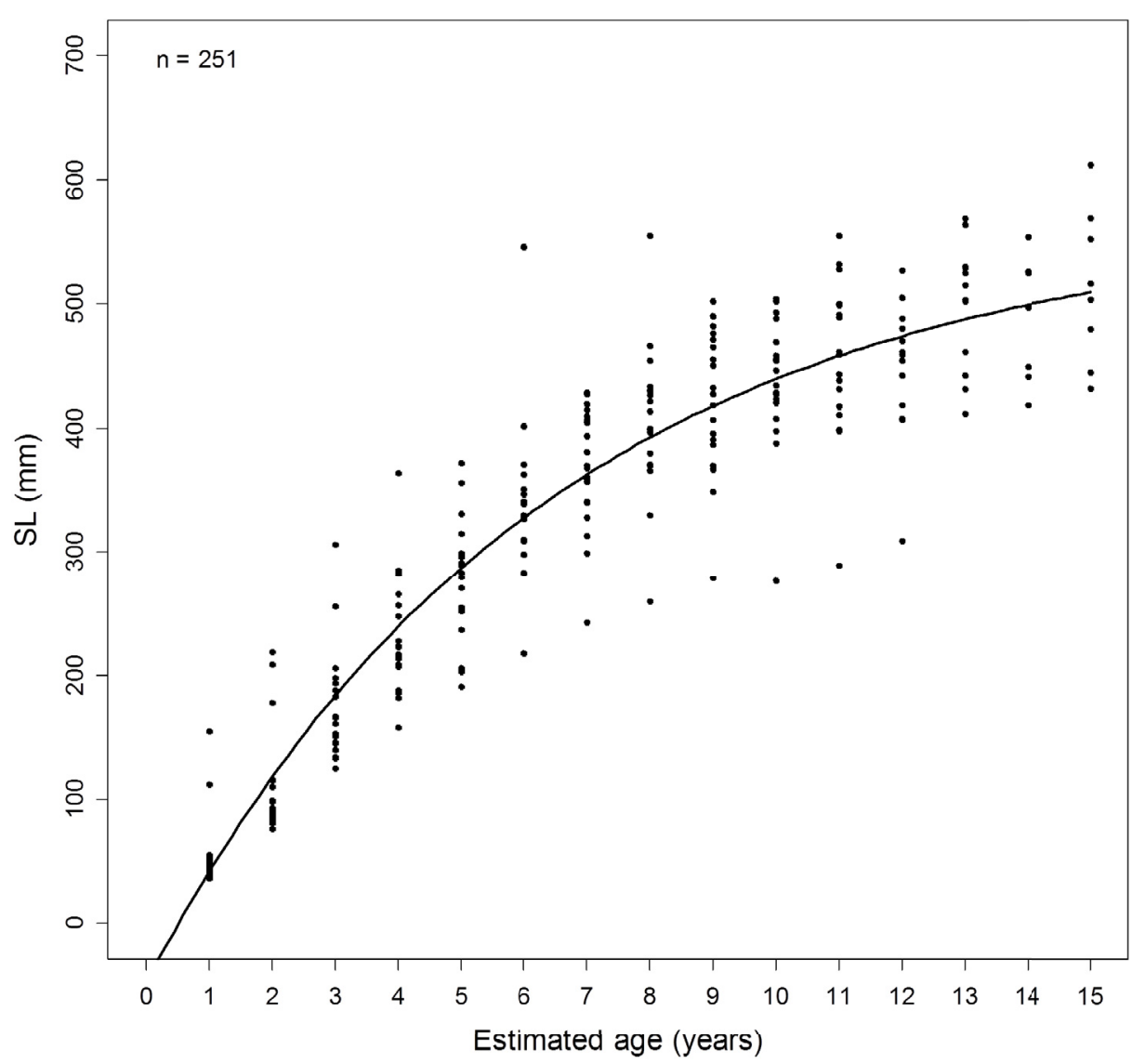

Figure 6

Overall VBGM for 25 stocks of B. barbus in England (cf. Table IV).

Indeed, the sensitivity of larger barbel (i.e. $>100 \mathrm{~mm} \mathrm{SL}$ ) to reduced habitat was demonstrated in Reach 3, where in an earlier study a significant decrease in mean SL (from 330 to $202 \mathrm{~mm}$ ) was observed following removal of in-stream and over-hanging branches from that reach (Copp and Bennetts, 1996). Alternatively, this gap could be an artefact of interannual variations in recruitment or that of the discontinuous nature of this river system, which inhibits free movement of $B$. barbus, and thus biasing perception of the overall population structure.

The present study has evaluated bias and precision of age estimates in $B$. barbus, even though Britton et al. (2012) utilised a quality control procedure to minimise errors in age estimation based on the evaluation of a set of scales from each individual fish. Evaluation of bias and precision in fish age-growth studies is a valuable means, inter alia, of comparing the skill level of one interpreter relative to that of others (Campana, 2001), and the present study indicated a tendency for two (i.e. B and C) of the three interpreters to count more annuli relative to those counted by the other interpreter $(A)$. A reason for this discrepancy could be attributable to the greater experience in ageing fish by Interpreter A (LV) relative to $B$ and $C$. On the other hand, it can be argued that for the same reason Interpreter A may have been inclined to take a more conservative approach due to concerns with the limitations of scales relative to other structures in ageing older fish (e.g. Vilizzi et al., 1998; Vilizzi and Walker, 1999). This assumption for $B$. barbus remains conditional on future comparative studies that are based on different ageing structures. Clearly, validation studies of the ages of $B$. barbus in the $R$. Lee will help resolve these interpretability issues, even though always within the constraints of age estimates based on non-destructive techniques (e.g. removal of scales), as opposed to methods involving the sacrifice of fish (e.g. otolith extraction), due to the conservation value of $B$. barbus populations in England (Britton and Pegg, 2011; Pegg and Britton, 
2011). Finally, the APE and CV values achieved in the present study, albeit higher than those reported as 'desirable' in the age-growth literature (i.e. APE $<5.5 \%$ and CV $<7.6 \%$ ), were still in accordance with those reported for scales (Campana, 2001).

The importance of precision in the scale age estimates relates to their role in assessing the age and growth rates of the R. Lee $B$. barbus in relation to other populations. Individuals were aged to age 10 and although this suggests that $B$. barbus were capable of a relatively long life span in the river, individual barbel in other English rivers have been recorded to be at least 20 years old (Britton et al., 2012). Given the number of individual fish sampled in the R. Lee, it was assumed that no age classes were missed and so 10 years is close to their maximum attainable age under those river conditions. The SL-at-age data and growth models from the R. Lee were in accordance with other UK riverine populations and also those in Europe (e.g. Przybylski et al., 2004; Prokeš et al., 2006). Nevertheless, the SL-at-age data suggested a large growth increment in the first year of life compared with other rivers, with slowing thereafter and producing a maximum theoretical length $(518 \mathrm{~mm})$ that whilst in the range of other populations, may still be considered relatively low. Similar to the factors affecting $B$. barbus recruitment outlined above, these growth characteristics were acquired from three reaches within a much larger river basin but may be considered symptomatic of the environmental conditions of the habitats and their disconnection, i.e. favourable in the initial years of life for $B$. barbus but potentially limiting thereafter.

In summary, the present study reveals that the declining $B$. barbus stocks in the R. Lee was probably related to a recruitment bottleneck surrounding the progression of the $300-340 \mathrm{~mm}$ SL class into larger size classes, most probably linked to insufficient available habitat for fish of that size range and in the absence of known stocking (M. Carter, pers. comm.). Juvenile growth and recruitment does not appear to be problematic and thus options for improved management of the aquatic ecosystem from a $B$. barbus perspective should consider aspects of improved longitudinal connectivity and adult habitat enhancement, rather than focusing on spawning and nursery areas.

\section{ACKNOWLEDGEMENTS}

We thank the Hertfordshire \& Middlesex Wildlife Trust, Welwyn Garden City Council, the Cecil Gascogne Estates, and the late Mrs Lucas for permission to carry out our investigations on their stretches of the River Lee. We also thank, T. Bennetts, J. Černý, R. Cortes, S. Doherty, K. Haynes, V. Jubb, J. Majecki, S. Newby, W. Pegg, M. Watkins, K.J. Wesley, and the late S. Smith for assistance in the field.

\section{REFERENCES}

Abernethy D.L., 2006. An angler's guide to interpreting Alabama wildlife and freshwater fisheries reservoir reports. Department of Conservation and Natural Resources, Wildlife and Freshwater Fisheries Division, Fisheries Section, Alabama USA. http://www.outdooralabama.com/fishing/freshwater/ where/reservoirs/guide.pdf

Britton J.R. and Pegg J., 2011. Ecology of European barbel Barbus barbus: implications for river, fishery, and conservation management. Rev. Fish. Sci., 19, 321-330.

Britton J.R., Davies G.D. and Pegg J., 2012. Spatial variation in the somatic growth rates of European barbel Barbus barbus: a UK perspective. Ecol. Freshwat. Fish, 22, 21-29.

Burnham K.P. and Anderson D.R., 2003. Model selection and multimodel inference. a practical information-theoretic approach. New York, Springer.

Campana S.E., 2001. Accuracy, precision and quality control in age determination, including a review of the use and abuse of age validation methods. J. Fish Biol., 9, 197-242.

Campana S.E., Annand M.C. and McMillan J.I., 1995. Graphical and statistical methods for determining the consistency of age determinations. Trans. Am. Fish. Soc., 124, 131-138. 
Cattanéo F., 2005. Does hydrology constrain the structure of fish assemblages in French streams? Local scale analysis. Arch. Hydrobiol., 164, 345-365.

Charman D.J., 2010. Centennial climate variability in the British Isles during the mid-late Holocene. Quater. Sci. Rev., 29, 1539-1554.

Charnov E.L., 2010. Comparing body-size growth curves: the Gallucci-Quinn index, and beyond. Environ. Biol. Fish., 88, 293-294.

Chugunova N.I., 1963. Age and growth studies in fish. Office of Technological Services, Washington, D.C.

Clarke K.R. and Gorley RN., 2006. PRIMER v6: User Manual/Tutorial. PRIMER-E Ltd, Plymouth, UK.

Copp G.H. and Bennetts T.A., 1996. Short-term effects of removing riparian and instream cover on barbel (Barbus barbus) and other fish populations in a stretch of English chalk stream. Folia Zool., 45, 283-288.

Copp G.H., Doherty S., Faulkner H., Watkins M.S. and Majecki J., 2002. Diel drift behaviour of fish eggs and larvae, in particular barbel, Barbus barbus (L.), in an English chalk stream. Fish. Manag. Ecol., 9, 95-104.

Copp G.H., Fox M.G., Przybylski M., Godinho F. and Vila-Gispert A., 2004. Life-time growth patterns of pumpkinseed Lepomis gibbosus introduced to Europe relative to native North American populations. Folia Zool., 53, 237-254.

Copp G.H., Spathari S. and Turmel M., 2005. Consistency of diel behaviour and interactions of stream fishes and invertebrates during summer. Riv. Res. Appl., 21, 75-90.

Copp G.H., England J., Tyner R., Carter M.G., Przybylski M. and Wesley K.J., 2007. Growth and condition of dace Leuciscus leuciscus in the River Lee (Hertfordshire) relative to selected populations elsewhere in Europe. London Nat., 86, 71-85.

Edmonds-Brown V., Copp G.H. and Majecki J., 2004. Diel patterns of drift by macroinvertebrates in the River Lee (Hertfordshire) during low discharge. London Nat., 83, 145-157.

Faulkner H. and Copp G.H., 2001. A model for accurate drift estimation in streams. Freshwater Biol., 46, 723-733.

Gabelhouse D.W., 1984. A length-categorization system to assess fish stocks. North Am. J. Fish. Manage. 4, 273-285.

Hoenig J.M., Morgan M.J. and Brown C.A., 1995. Analysing differences between two age determination methods by tests of symmetry. Can. J. Fish. Aquat. Sci., 52, 364-368.

Huet M., 1949. Aperçu de la relation entre la pente et les populations piscicoles des eaux courantes. Schweiz. Z. Hydrol., 11, 332-351.

Hunt P.C. and Jones J.W., 1975. A population study of Barbus barbus L. in the River Severn, England. III. Growth. J. Fish. Biol., 7, 361-376.

Lucas M.C. and Frear P.A., 1997. Effects of a flow-gauging weir on the migratory behaviour of adult barbel, a riverine cyprinid. J. Fish Biol., 50, 382-396.

NRA, 1994a. Upper Lee catchment management plan: Final plan. National Rivers Authority, Thames Region, Reading, UK

NRA, 1994b. Implementation of the Freshwater Fish Directive: water quality requirements for the support of fish life. National Rivers Authority, Rivers House, Waterside Drive, Aztec West, Almondsbury, Bristol, England.

Ogle D., 2011a. FishR vignette - Size structure analysis. Northland College, Wisconsin, USA, 16 p., http://www.ncfaculty.net/dogle/fishR/gnrlex/SizeStructure/SizeStructure.pdf.

Ogle D., 2011b. FishR vignette - Precision and accuracy in ages. Northland College, Wisconsin, USA, 11 p., http://www.ncfaculty.net/dogle/fishR/gnrlex/AgeComparisons/AgeComparisons.pdf.

Ogle D., 2011c. FishR vignette - Length-weight relationships. Northland College, Wisconsin, USA, 12 p., http://www.ncfaculty.net/dogle/fishR/gnrlex/LengthWeight/LengthWeight.pdf.

Ogle D., 2011d. FishR vignette - Size structure analysis. Northland College, Wisconsin, USA, 54 p., http://www.ncfaculty.net/dogle/fishR/gnrlex/VonBertalanffy/VonBertalanffy.pdf.

Pegg J. and Britton J.R., 2011. Effects of inter- and intra-specific competition on the growth rates of juvenile European barbel Barbus barbus used in the stock enhancement of UK fisheries. Fish. Res., 112, 8-12. 
Peňáz M. and Štouračová I., 1991. Effect of hydroelectric development on population dynamics of Barbus barbus in the River Jihlava. Folia Zool., 40, 75-84.

Peňáz M., Pivnička K., Baruš V. and Prokeš M., 2003. Temporal changes in the abundance of barbel, Barbus barbus in the Jihlava River, Czech Republic. Folia Zool., 52, 441-448.

Peňáz M., Svobodová Z., Baruš V., Prokeš M. and Drastichová J., 2005. Endocrine disruption in a barbel, Barbus barbus population from River Jihlava, Czech Republic. J. Appl. Ichthyol., 21, 420-428.

Persat H. and Chessel D., 1989. Typologie de distributions en classes de taille: intérêt dans l'étude des populations de poissons et d'invertébrés. Acta CEcol., CEcol. Gen., 10, 175-195.

Pilcher M. and Copp G.H., 1997. Winter distribution and habitat use of fish in a regulated lowland river system of South-East England. Fish. Manag. Ecol., 4, 199-215.

Pilcher M., Copp G.H. and Szomolai V., 2004. A comparison of adjacent natural and channelised stretches of a lowland river. Biologia-Bratislava, 59, 669-673.

Prokeš M., Šovčík P., Peňáz M., Baruš V., Spurný P. and Vilizzi L., 2006. Growth of the barbel, Barbus barbus, in the River Jihlava following major habitat alteration and estimated by two methods. Folia Zool., 55, 86-96.

Przybylski M., Boron A. and Kruk A., 2004. Growth of barbel, Barbus barbus (L.) in the upper Warta River, Odra River system. Ecohydrol. Hydrobiol. 2, 183-190.

R Development Core Team, 2010. R: A language and environment for statistical computing. R Foundation for Statistical Computing, Vienna, Austria. http://www.R-project.org.

Ricker W.E., 1975. Computation and interpretation of biological statistics of fish populations. Bull. Fish. Res. Board Can., 191.

Taylor A.A.L., Britton J.R. and Cowx I.G., 2004. Does the stock density of stillwater catch and release fisheries affect the growth performance of introduced cultured barbel? J. Fish Biol., 65 (Suppl. A), 308-313.

Tyler C.R. and Everett F., 1993. Incidences of gross morphological disorders in barbel (Barbus barbus) in three rivers in southern England. J. Fish Biol., 43, 739-748.

Vilizzi L. and Copp G.H., 2001. Behavioural responses of 0+ barbel in an artificial stream: distribution and velocity use. Animal Behav., 61, 645-654.

Vilizzi L. and Copp G.H., 2013a. Interstitial movement and emergence of barbel, Barbus barbus, free embryos and larvae in a laboratory flume. J. Fish Biol., 82, 1057-1063.

Vilizzi L. and Copp G.H., 2013b. Bias, precision and validation of ageing 0+ European barbel Barbus barbus (L.) from their otoliths. Cent. Eur. J. Biol. 8, 654-661.

Vilizzi L. and Walker K., 1999. Age and growth of the common carp, Cyprinus carpio, in the River Murray, Australia: validation, consistency of age interpretation, and growth models. Environ. Biol. Fish., 54, 77-106.

Vilizzi L., Walker K.F., Jain T., McGlennon D. and Tsymbal V., 1998. Interpretability and precision of annulus counts for calcified structures in carp, Cyprinus carpio L. Archiv Hydrobiol., 143, 121127.

Vilizzi L., Copp G.H., Peňáz M. and Carter M.G., 2006. Movement and abundance of barbel Barbus barbus in a mesotrophic chalk stream: the River Lee, England. Folia Zool., 55, 183-197.

Watkins M.S., Doherty S. and Copp G.H., 1997. Microhabitat use by 0+ and older fishes in a small English chalk stream. J. Fish Biol., 50, 1010-1024.

Wheeler A. and Jordan D.R., 1990: The status of the barbel, Barbus barbus (L.) (Teleostei, cyprinidae), in the United Kingdom. J. Fish Biol., 37, 393-399.

Živkov M.T., Trichkova T.A. and Raikova-Petrova G.N., 1999. Biological reasons for the unsuitability of growth parameters and indices for comparing fish growth. Environ. Biol. Fish., 54, 67-76. 